\title{
Miranda
}

Revue pluridisciplinaire du monde anglophone /

Multidisciplinary peer-reviewed journal on the English-

speaking world

19 | 2019

Rethinking Laughter in Contemporary Anglophone Theatre

\section{Pushing for Efficiency: Gifford Pinchot and the First National Parks}

Jean-Daniel Collomb

\section{OpenEdition}

\section{Journals}

\section{Electronic version}

URL: http://journals.openedition.org/miranda/20268

DOI: 10.4000/miranda.20268

ISSN: 2108-6559

\section{Publisher}

Université Toulouse - Jean Jaurès

\section{Printed version}

Date of publication: 7 October 2019

\section{Electronic reference}

Jean-Daniel Collomb, "Pushing for Efficiency: Gifford Pinchot and the First National Parks", Miranda

[Online], 19 | 2019, Online since 07 October 2019, connection on 16 February 2021. URL: http:// journals.openedition.org/miranda/20268 ; DOI: https://doi.org/10.4000/miranda.20268

This text was automatically generated on 16 February 2021.

\section{cc) (i) () $\Theta$}

Miranda is licensed under a Creative Commons Attribution-NonCommercial-NoDerivatives 4.0 International License. 


\title{
Pushing for Efficiency: Gifford Pinchot and the First National Parks
}

\author{
Jean-Daniel Collomb
}

1 American environmentalism began to slowly emerge at the end of the $19^{\text {th }}$ century. The concept of the National Park materialized in 1864 with the creation of Yosemite Park (although Yellowstone was the first park to be actually called a National Park in 1872) and, henceforth, a growing number of Americans started to see nature more positively than previous generations had done. Yet, from the outset the US environmental movement proved heterogeneous. Indeed, as the National Park System was growing larger and larger, the so-called conservation movement came into being in large part thanks to Gifford Pinchot who was appointed as the first chief of the Forest Service in 1905. A clear gap existed between the principles that underpinned early conservationist efforts and the intended purposes of the first parks. The rift between utilitarian conservation and preservationism as revealed by the now well-known Hetch Hetchy controversy-in which the former prevailed over the latter-springs to mind (Jones, Righter).

2 In order to better comprehend this dichotomy, it seems worth probing into the attitudes of the first conservationists with regards to the National Parks. There is no question that Gifford Pinchot opposed the development of the National Park System. One may even argue that he found it very difficult to even acknowledge the legitimacy of the concept of the National Park. His strong reservations concerning the parks were the result of the values on which conservation was founded in the first place. Its proponents, who saw it as their mission to master nature through the use of science and technology, had very little time for the warnings and protests voiced by the preservationists.

3 This article is a contribution to the debate over the ideology of early $20^{\text {th }}$-century utilitarian conservationists. It focuses on Gifford Pinchot, the first chief of the US Forest Service and the most influential member of the founding generation of utilitarian conservation in the US. The article looks at how he viewed the National 
Parks and attempts to explain why his clash with preservationists, which became apparent during the Hetch Hetchy controversy, was inevitable.

4 According to John M. Meyer, the much-discussed controversy between preservationists and conservationists at the turn of the $20^{\text {th }}$ century was rooted in differing conceptions of political action rather than in two opposed visions of nature. Because Gifford Pinchot viewed guaranteed access to natural resources as the foundation on which the political order hinged, Meyer suggests, he argued that the promotion of such access had to take precedence over all other concerns. Meyer is quick to add, however, that Pinchot was not indifferent to nature's beauty although his conception of political action prompted him to keep his aesthetic sensitivity private (267-284).

5 Aware that Gifford Pinchot's standing in contemporary environmental circles pales in comparison to the posthumous prestige enjoyed by John Muir (Frome), Gifford Pinchot's main biographer, Char Miller, has also tried to rehabilitate Pinchot's reputation by belying the simplistic portrayal of Pinchot as a monomaniacal utilitarian engineer whose idée fixe was to maximize US timber production. Miller has successfully demonstrated that Pinchot was much more than that: a progressive-minded leader who worried about the fate of industrial workers and supported federally-sponsored relief for the dispossessed during the Great Depression; a strong advocate for world peace; and, even more importantly for the purpose of this article, a nature lover who could also appreciate the spiritual, recreational and aesthetic values of the natural world (Miller 1992, 1-20).

6 Meyer's and Miller's efforts to rehabilitate Pinchot's legacy in environmental memory boil down to arguing that the former chief of the Forest Service did also value some non-economic aspects of the natural world so that his record goes well beyond the single-minded focus of the early Forest Service on timber production. In the end, however, Miller's and Meyer's revised portrayal of Pinchot is only successful in making him a more complex character than he is often depicted as but in no way does it invalidate the characterization of his contribution to US conservation as completely focused on a scientifically-informed exploitation of the nation's natural resources for the material benefit of the American people. If anything, the fact that Pinchot was actually sensitive to the aesthetic dimension of nature but that he would not allow such a predisposition to shape his vision of conservation at all bears witness to the tremendous influence that a sort of Saint-Simonian mindset exerted on early $20^{\text {th }}$ century conservationists. In short, we can be grateful to Miller and Meyer for providing us with a subtler picture of Pinchot's personality, but not of his record as a conservationist.

7 The article begins with an analysis of the parallels between Saint-Simonianism and Gifford Pinchot's brand of conservation. It then turns to Pinchot's attitude regarding the National Parks and, more broadly, to the rationale that undergirded his rejection of them. In the process, it draws on Jacques Ellul's reflections on the dynamics of the socalled "technological society". The article ends with a discussion of the impact of Pinchot's approach to conservation on the chances of success of his preservationist adversaries during the Hetch Hetchy controversy. In an era when the search for efficiency defined the public policy agenda to a considerable degree, making a case for the spiritual and aesthetic values of Hetch Hetchy Valley was bound to have a limited political impact. 


\section{Saint-Simon in America}

8 In order to shed light on the intellectual foundations of conservation, one inevitably has to turn to Gifford Pinchot who, in his autobiography, claimed that he fathered the notion (319-339). Pinchot, an American citizen of French descent who had been raised in a wealthy New York family, was the first full-fledged professional forester on American soil. In 1897 he was appointed as head of the Division of Forestry, then a section of the Department of the Interior. He then went on to manage the national forests $^{1}$ as head of the Forest Service, from its creation in 1905 to 1911, when President William Howard Taft dismissed him. The first part of this article is aimed at demonstrating that Gifford Pinchot came to embody the ideal of the Saint-Simonian engineer in the United States. Even though Pinchot did not explicitly subscribe to the theories developed by Saint-Simon-and indeed never seems to have mentioned him-he appears to have had a lot in common with Claude-Henri de Rouvroy de SaintSimon.

9 Saint-Simon developed his ideas from the early $19^{\text {th }}$ century until he died in 1825 . His death did not spell the end of his ideas-quite the opposite in fact. His theories outlived him and became influential in some elite circles in and outside France. Put simply Saint-Simon called for the advent of a society organized along rational lines by the implementation of scientific knowledge under the aegis of an enlightened elite. In order to achieve this purpose, he believed that it was crucial to bring about the domination of the so-called productive classes which were composed of industrialists, scholars, and artists. The administration of Saint-Simonian society hinges on two key principles: a desire to do away with democratic politics and a profound mistrust of economic laisser-faire. To Saint-Simon the free market and the parliamentary regime tend to create chaos and foster inefficiency and social disunity. That is why SaintSimon favored government by a rational and educated elite: "[...] it is monstrous that the teaching of morals and that of scientific knowledge be entrusted to two distinct bodies; because it is monstrous that ignorant people be asked to govern those who are enlightened." (translation mine) (189) According to Antoine Picon, a leading expert on Saint-Simonianism, the French philosopher intended to usher in "a peaceful organization of labor resting on the rational allocation of land, equipment, machinery and capital" (64) (translation mine). In other words, he argued for the development of large-scale, coordinated networks to organize production. There is undeniably an inherent tension between the interventionist and hierarchical ideals of SaintSimonianism and its promotion of such networks. This brief description of SaintSimonianism would be incomplete without mentioning the religious dimension of the movement, apparent in the wish of its early leaders to replace churches by institutions of their own (67).

One may wonder about the connection between Saint-Simon's ideas and those of the conservationists who staffed the US Forest Service during the Progressive Era. At first glance likening a philosophical school whose modest heyday occurred in 1830s France to the intellectual foundations of a federal agency which came into being in early- $20^{\text {th }}$ century America might appear far-fetched. Yet one should bear in mind that Gifford Pinchot had studied in France at the École Nationale Forestière of Nancy in 1889, before joining a German university the following year. The author of this article posits that Pinchot was exposed to the influence of Saint-Simonian thought while in France. A few 
years after returning to the United States, Gifford Pinchot came close to the archetype of the Saint-Simonian engineer. The conservationist policies he implemented while in charge of the Forest Service can be characterized as American-style Saint-Simonianism.

11 In his introduction to the seminal study of conservation during the progressive era, Samuel P. Hays describes conservationism as a movement of a scientific kind, adding that "its essence was rational planning to promote efficient development and use of all natural resources" (2). On further examination, several similarities between SaintSimonianism and utilitarian conservation emerge. Both schools of thought put a premium on a brand of science emphasizing action. In that regard, early conservationists seemed to have partaken of the spirit of positivism. In their view, science mattered mostly insofar as it could have practical repercussions, namely technical realizations. Pinchot's temperament and actions symbolize this cult of action. "No man can be happy without a job," he wrote in his autobiography entitled Breaking New Ground (49).

12 Although he paid lip service to the proverbial American democratic spirit throughout his autobiography and he was elected governor of Pennsylvania twice after 1923, Pinchot often expressed a typically Saint-Simonian desire to by-pass democratic politics. As a high-ranking civil servant in the federal bureaucracy, he did his utmost to ensure that his initiatives would be placed beyond the reach of the democratic process which he viewed as much too volatile and ineffective. In Breaking New Ground he bemoans the harmful consequences of the spoils system ${ }^{2}$ which gave priority to political hacks over competent civil servants (132). In this book, politics, most markedly at the local level, is portrayed as a source of disorder, wrongdoings and, even worse from a Saint-Simonian perspective, inefficiency. Pinchot is also highly critical of the members of the General Land Office whose job was to manage the forest reserves until 1905 , when this function was transferred to the Forest Service $(161,244)$. Pinchot pinned his hopes on the executive branch of the federal government led by Theodore Roosevelt who foreshadowed the modern presidency, at least in his intentions. In short, Pinchot personified the fascination for experts and engineers that was so typical of the Progressive Era.

13 Furthermore, Pinchot's brand of conservation was predicated on a questioning of the sacredness of private property-arguably one of the founding values of the American republic. From the very early days of the republic, elected officials had set out to privatize the public domain as quickly and thoroughly as possible (Allin chap. 1). Pinchot was well aware that a land-management policy of this kind would make genuine conservation a dead letter. As a matter of fact it would have been the very negation of the brand of conservation he envisioned. Hence his attempts to draw the attention of his contemporaries on the harmful consequences of making land and resources too easily accessible to private interests. A disengaged federal government, Pinchot argued, fostered destructive exploitation of nature. In order to reverse this trend, he advocated regulation of commodity exploitation by the federal government, which would look after the common good in the long term. Unsurprisingly, he did not feel nostalgic for the unbridled capitalism of the Gilded Age: "It is time for America and the world to move on from a social order in which unregulated profit is the driving force. [...] When it comes, I hope and believe the new order will be based on cooperation instead of monopoly, on sharing instead of grasping, and that mutual helpfulness will replace the law of the jungle." (509) The federal government, in other 
words, ought to act as a regulating force with a view to averting the chaos begotten by laisser-faire.

Utilitarian conservation's chief purpose was to make American society function more efficiently. In that respect, it captured the spirit of the age perfectly. The dedication of Pinchot's followers to the drive for efficiency is undeniably a by-product of the progressive impulse in American life at the beginning of the $20^{\text {th }}$ century. John W. Chambers has identified two main trends at work during the Progressive Era; trends which sometimes turned out to be contradictory. Firstly, most progressive reformers attempted to seize the moral high ground, hoping to restore the American republic to its original purity. Secondly, many progressives were willing to promote efficiency in fields as diverse as municipal politics, labor law, business regulations, and the management of natural resources (Chambers 169). That is why conservationism can be defined as a Baconian endeavor to master nature through the use of science and technology for the benefit of the American people. Consider, for instance, Pinchot's interest in what he called the "problem of national efficiency" (349). His definition of forestry leaves little doubt as to the values and objectives of the Forest Service: "Forestry is Tree Farming. Forestry is handling trees so that one crop follows another. To grow trees as a crop is Forestry." (31) Pinchot pledged that conservation would allow his fellow Americans to take advantage of American forests in the most complete way imaginable. In order to achieve this purpose, he unwittingly upheld the SaintSimonian plea for government by experts, largely insulated from the influence of elected officials.

That is why Pinchot was desperate to figure out a Saint-Simonian way of recruiting Forest Service agents. In order to thwart the political nepotism of the General Land office which he thoroughly despised, he advocated for recruitment by way of competitive examination. Thus, the competent and enthusiastic recruits who joined the Service under Pinchot's leadership emerged as the ideal figures of American SaintSimonianism, thanks to their technical expertise and their desire to serve the common good.

The Messianic spirit and optimism consubstantial to progressivism is yet another similarity between the Saint-Simonian and the conservationist traditions. Although they never indulged in the sort of religious frenzy experienced by Saint-Simon's disciples in the 1830s, it can hardly be denied that the leaders of American conservationism enthusiastically embraced the gospel of progress, as is made evident by the following excerpt from Pinchot's autobiography: "The rightful use and purpose of our natural resources is to make all the people strong and well, able and wise, welltaught, well-fed, well-clothed, well-housed, full of knowledge and initiative, with equal opportunity for all and special privilege for none." (509-510) Unwittingly emulating Saint-Simon's example, Pinchot firmly believed that the implementation of scientific research would pave the way for a better world. He even argued that utilitarian conservation could be used as a means by which to preserve world peace. Although it only focuses on the early decades of the $20^{\text {th }}$ century, Breaking New Ground was published after World War II. Pinchot stated that implementing conservationist principles internationally would ensure better distribution of resources and create bonds between countries that would make armed conflicts less likely (505-506).

On this point, Michael B. Smith goes even further: "Pinchot [...] was intent on building an institution, a 'church of conservation'. He was concerned not with the spiritual 
renewal of the individual but with the salvation of the nation, and his crusade was for the common good, organized and directed by experts, the high priests of the Forest Service." (759) To its most ardent defenders, utilitarian conservation felt like a new form of secular religion. No wonder then that Samuel P. Hays titled his study of early $20^{\text {th }}$-century conservation Conservation and the Gospel of Efficiency.

Conservation in its early phase amounted to a reaffirmation of utilitarianism. Interestingly, Pinchot paraphrased the oft-quoted utilitarian motto invented by Jeremy Bentham, modifying it slightly in the process: "[...] the use of the natural resources for the greatest good of the greatest number for the longest time." (326) It is worth remembering that before Gifford Pinchot came into prominence, forestry, namely the rational management of forests as was already being practiced in Western Europe, did not exist in the United States.

Although Pinchot differed from the traditional advocates of Saint-Simonianism in that he explicitly supported democracy and did not condemn the market system per se, in practice he often found that democracy and the marketplace, far from enhancing his vision, ended up frustrating it. For instance, he initially hoped to cooperate with the timber industry in the Pacific Northwest in order to promote scientific forestry in the region, but he gradually came to the realization that such an approach failed to produce results and eventually recommended "a stiff dosage of federal regulation" (Ficken 177), which put him at odds with the timber industry. Likewise, there is no reason to doubt that Pinchot and his backers were sincere in their belief that utilitarian conservation was a "struggle on behalf of the people against the depredations of the monopolies" (Clements 1979, 190) but they failed to recognize that their vision of government and public policy was much closer to technocracy than to liberal democracy as conceived at the time.

Brian Balogh, who has underlined the progressive conservationists' suspicion of democratic institutions and legislative maneuvers, has drawn a list of their fundamental principles that is strongly reminiscent of the Saint-Simonian agenda: "Neutral expertise, esprit de corps, solicitude for the general good over the grasping machinations of special interests, a preference for executive action, and centralized control over crucial elements of the economy previously left to the private sector." (199) This list goes a long way toward accounting for the permanent tension between Pinchot's vocal dedication to the democratic ideal (couched in utilitarian terms) and his largely technocratic prescriptions (Clements 1980, 282).

It seems fair to state therefore, that mutatis mutandis, the early Forest Service did introduce a new, albeit slightly modified, version of Saint-Simonianism in America. This philosophical and scientific background may help us better understand the attitudes of early- $20^{\text {th }}$ century conservationists regarding National Parks.

\section{Early conservationists and the National Parks}

When broaching the first efforts made by Americans to protect nature, historians are wont to pit conservation against preservation. Although the former does form a coherent whole, defining the latter is no easy task since its meaning really depends on the frame of mind and values embraced by its proponents. More often than not preservationists tended to call for the protection of certain landscapes for recreation and for aesthetic and therapeutic purposes. Defending the National Parks was the 
domain of those who are now known as preservationists. In its founding charter, the Sierra Club, which was created in 1892, defined its chief objective in an unequivocal way: preserving the forests and landscapes of the Sierra Nevada (Cohen 8-10). This stated objective-to protect the sanctity of the park-reflects what preservation stood for. John Muir and his editor Robert Underwood Johnson, who first conceived the idea of the Sierra Club, were willing to impose a limit on commodity exploitation by substituting to it the aesthetic and patrimonial uses of the dazzling landscapes of the American West. In the first pages of Breaking New Ground, Pinchot chose to distance himself from the preservationists: "Their eyes were closed to the economic motive behind true Forestry. They hated to see a tree cut down. So do I, and the chances are that you do too. But you cannot practice Forestry without it." (28) The proponents of utilitarian conservation had little time for aesthetics, at least when it came to the public policies they advocated. John Muir wrote about sublime nature whilst Gifford Pinchot concerned himself with the profitability and productivity of the forests of America.

The early conservationists found it difficult to even accept the National Park idea. Pinchot, for instance, blamed preservation for banning commodity exploitation in areas where, he believed, it could have been carried out in a rational way. That is why he campaigned against the amalgamation of land in Wyoming to Yellowstone National Park (Hays 40). Pinchot could see no reason why the natural resources that could be exploited in an enlightened fashion would not be. This also explains why he dismissed the distinction between National Parks and Forest Reserves as misguided. As early as 1904, he tried to have the management of the parks transferred to the Department of Agriculture. Although he never gave up on this plan, his efforts remained in vain until he was dismissed from his position in 1911 (Steen 114). The reason why Pinchot tried so hard to obtain the management of the parks was because he disapproved of the way the Department of the Interior went about doing it. Ultimately, his goal was to ensure that parks would be managed according to the principle of maximum efficiency that already held sway in the Forest Reserves (renamed National Forests in 1907) (Pinchot 242). The historian of the US Forest Service, Harold K. Steen points out that their agents had very little interest in tourism and recreation in the early $20^{\text {th }}$ century (113). Conservation, as they saw it, could not be expected to heed such objectives. Put simply, early conservationists held that aesthetic and recreationist criteria could only apply in places where commodity exploitation was deemed impractical. Such a view is actually consistent with the rationale that had underpinned the creation of Yellowstone National Park in 1872. It was precisely because the area had not been deemed amenable to commodity exploitation that a park dedicated to tourism had been created, with the active support of railway companies eager to make the most of the tourism business (Runte 50-54).

It is worth noting that Pinchot is not the only conservationist to have rejected preservation. This rejection stemmed from the values and attitudes prevalent in the Forest Service as shown by the policy put in place by Henry S. Graves, who took over from Pinchot as chief of the Service in 1911. It did not take long before Graves expressed his wish to be involved in the management of National Parks. Like Pinchot, Graves did not favor the creation of a federal agency devoted to the management of the parks. To him, such an initiative would not be warranted as the Forest Service was already in a position to manage them rationally in accordance with conservationist 
principles. According to Harold K. Steen, Graves reluctantly considered recreation out of necessity but never came close to regarding it as a priority. Thus Graves kept a watchful eye on the potential enlargement of the parks and strove to limit it as much as he could. He argued that only the areas featuring trees with high aesthetic potential should be added to the park system whilst trees with high commercial value should be excluded from it (Steen 114-116).

What really mattered to the leadership of the Forest Service was to set in motion a coordinated and large-scale project with a view to controlling the use of natural resources on a national scale. This, they believed, would enhance American prosperity, and the National Parks were to be no exception. Still Henry S. Graves did have to strike some compromises. He went as far as to admit recreation as a secondary use of the National Forests. This move should not be interpreted as an ideological shift. Realizing that the parks were becoming more and more popular, Graves thought that he was about to witness the marginalization of his agency. He did not lose hope however. He continued to hope that sooner or later the parks would be put under the jurisdiction of conservationists like himself (Steen 122). In 1916, when the National Park Service eventually came into being, the Forest Service was dealt a humiliating blow. Not only was the Forest Service not awarded the management of the parks but it also had to contend with a rival whose raison d'etre did not align with the conservationist agenda. After 1916 the relations between the two agencies did not always go smoothly. The competition of the National Park Service even prompted the Forest Service to make more room for recreation within the National Forests (Sellars 58). The fact remains, however, that the conservationists were very reluctant to accommodate the preservationist ideal that had shaped the development of the National Park System. The conservationist rejection of the inviolability of parks stemmed from the principles propounded by Gifford Pinchot and his followers. In order to better understand the conceptual reasons for this stance, it may be useful to turn to the work of the French philosopher Jacques Ellul. In the context of modernity, far from applying only to machinery, technology, he writes, morphed into an ethos which elevates the search for efficiency above all other concerns (Ellul 1988, 56).

Ellul casts technology as the main determinant of modern life after the scientific and industrial revolutions. To him, the so-called technological society amounts to a rational ordering of all human activities, whether material or psychological, with one single objective-to foster efficiency. In such a context, Ellul claims, technology is set to "algebrize the world" (translation mine) (Ellul 1988, 274). In the technological society, all places, all phenomena, and all activities are liable to be submitted to technology sooner or later. A quote by Henry David Thoreau beautifully foreshadowed Ellul's thinking: "Men have become the tools of their tools." (25) Ellul holds that any objective or attitude which does not dovetail with the technological agenda is gradually marginalized or absorbed by it: "Technological progress now stems from the search for efficiency only. [...] An individual is allowed to take part only insofar as he or she discards all the concerns which are now regarded as being of minor importance like aesthetics, ethics or imaginativeness." (Ellul 1954, 69) The process of marginalization of aesthetic and ethical criteria echoes the triumph of practicality analyzed by Leszek Kolakowski in his study of positivism (118).

One may argue that the attitudes of the members of the Forest Service regarding the parks provide an illustration of Ellul's reflections on the technological society. Gifford 
Pinchot's position is a case in point. In 1885, for instance, the state of New York passed a law to preserve a section of the Adirondack Mountains. In 1892, the area concerned became a park known as the State Forest Preserve. Two years later a provision banning tree cutting was added to the State constitution. It stipulated that the preserved area was to remain "forever wild" (Allin 30), which incensed Gifford Pinchot. In Breaking New Ground, he calls this provision "indefensible" (27). He worked hard to get it repealed-all to no avail. It did not make any sense to him that the nation should do without some of its valuable forest resources. Making this area inviolable precluded its being rationally exploited by conservationist foresters. Pinchot ascribed the "forever wild" provision to irrationality on the part of New York State officials: "[...] I have always regarded the sentimental horror of some good citizens at the idea of utilizing the timber of the Forest Preserve under Forestry as unintelligent, misdirected, and short-sighted." (182) In other words, technologically speaking, such restraint did not make any sense.

\section{Preservation and the technological society}

There is no question that the most spectacular illustration of the technological ethos at work in early conservation was the showdown over Hetch Hetchy Valley, which pitted Gifford Pinchot against John Muir toward the end of Muir's life. Philosophically, a large gap separated the two men. Although he strove to build consensus in order to enlist the support of public opinion for the National Parks, John Muir also developed innovative ideas foreshadowing late $20^{\text {th }}$-century radical environmentalism. Yet Muir chose to tone down his position, initially supporting utilitarian conservation. In Our National Parks, a book published in 1902, he stated that there were "legitimate demands on the forests" and went on to pay tribute to Pinchot's brand of conservation (263). Muir regarded it as highly preferable to the kind of laisser-faire which had prevailed throughout the period of westward expansion in the $19^{\text {th }}$ century. To him, conservation was an improvement on the environmentally harmful ways of the past. In reality, however, he felt slightly uncomfortable with it as he feared that the search for efficiency would know no limits if the likes of Pinchot had their way. So much so that, as time went by, Muir began to distance himself from the conservationist creed of the Forest Service. He seems to have been wary of the "algebrization" and invasion of the world by technology, to quote Jacques Ellul. Unlike Pinchot, Muir's involvement in public affairs was not an attempt to help the nation take complete control of its territory. For all his concessions to the spirit of the age, Muir was much more concerned by the health of nature in and for itself than by human welfare (1916).

Thus, the idea of the National Park provided Muir with an attractive opportunity to set limits to the supremacy of utilitarianism and productivism. In a nation developing at an accelerated pace and becoming ever more confident in its ability to control its territory and resources, the National Parks emerged as a pause and an obstacle to the expansion of technology and to the attempt to master nature by means of science and technology. This statement ought to be qualified because early preservationists approved of the construction of roads and hotels within the parks; tourism being a profitable business which railroad companies were quick to cash in on (Louter 250, Gutfreund 19). Be that as it may, the Parks were perceived by their proponents as places where commodity exploitation was to be barred, and where the beauty of landscapes was worth more 
than the commercial value of timber. John Muir subscribed to the notion that the parks had value in and for themselves although this ideal was not shared by all preservationists (Righter 82).

31 To the likes of Gifford Pinchot, Muir's position did not make any practical sense. The two men, who at first were on the best of terms, gradually moved away from each other. After 1905, the now famous Hetch Hetchy controversy staged the opposition between the two men in spectacular fashion. In the early 1900s, the city of San Francisco launched a dam building project in Hetch Hetchy Valley with a view to increasing the city's water resources. The problem was that the valley was located inside Yosemite National Park. The upshot of such a project would be to inundate a magnificent place. As a result, the Sierra Club, with the help of a few other organizations, campaigned against it. The combined efforts of the preservationists were successful in putting off the construction of the dam for several years. President Woodrow Wilson's election, however, dealt a mortal blow to the preservationist campaign: in 1913, the city of San Francisco was granted the permission to have the dam built. Throughout the controversy Gifford Pinchot had been steadfast in his support of the dam and had taken it upon himself to further San Francisco's interests by lobbying key decision-makers. He did so because he firmly believed that developing California's economy and infrastructures mattered much more than the aesthetic-let alone intrinsic-value of the valley. In his view, technology, as illustrated by the dam, would allow homo americanus to master his environment and to fully exploit its resources. As far as Pinchot was concerned, thwarting such a plan was irrational.

John Muir, who had initially supported utilitarian conservation, did his best to resist the conservationists' push for efficiency. Remaining true to their core principles, the conservationists abided by the technological impulse to use nature to the full whenever it was possible to do so. In the minds of Gifford Pinchot and his successor Henry S. Graves, the idea that Hetch Hetchy Valley, and more broadly the parks, ought to remain untouched was a conceptual error. Essentially, it would have boiled down to refraining from improving lands that could be exploited in a sustainable manner to serve human practical purposes. With Hetch Hetchy, Muir, who had thought that backing conservationism would put a brake on the excesses of the Frontier, came to the realization that it was Pinchot's turn to ignore limits.

In 1908, President Theodore Roosevelt ordered Pinchot to organize the Conference on the Conservation of Natural Resources. This conference was to be a forum to discuss the prospects of conservation in the United States with the main players involved. On drawing the guest list, Pinchot chose to by-pass John Muir (Miller 2001, 143-144). It would be a mistake to interpret this move as the result of any animosity between the two men. Char Miller has convincingly shown that there was no personal discord, despite the differences between Muir and Pinchot (119-144). At no point in Breaking New Ground does Pinchot criticize Muir. In fact, he pays tribute to the founder of the Sierra Club while making disparaging comments on Charles S. Sargent, a prominent Harvard botanist who had supported Muir's preservationist stance. The crux of the matter is that Pinchot was being consistent with his beliefs when he left Muir out of the conference. By attempting to put a limit on Pinchot's plan to take over the US territory and its resources-in other words by trying to curb the spiral of efficiency-Muir had excluded himself from the conservationist circle. From Pinchot's perspective, therefore, his presence would have lacked legitimacy. 

technological ethos in a nation whose population, economy, and industrial infrastructure were developing very rapidly. Yet it is also fair to point out, following Roderick Nash's argument, that the very fact that some organizations had managed to put off the construction of the dam for several years was in and of itself a remarkable achievement. A few decades earlier such a campaign would have been unthinkable (Nash 181). Furthermore, this controversy was instrumental in bringing about the creation of the National Park Service (1916), thus frustrating Pinchot's ambition to integrate the National Parks into the National Forests system (Righter 191). It should be added that the Hetch Hetchy controversy was a blueprint for other campaigns, most notably after 1945-several of which would turn out to be successful. The example of the dam project on the Echo Park River, located within the Dinosaur National Monument in Colorado, springs to mind. In 1956, the Sierra Club, along with other organizations, managed to kill the project (Turner). This being said, the imbalance between developmental objectives and preservationist concerns has remained self-evident to this day. That is because preservationist arguments are doomed to remain marginal in the technological society portrayed by Jacques Ellul.

From the very beginning, the advocates of the Park System set forth a highly heterogeneous set of arguments, which often paled in comparison with the rational consistency propounded by the Forest Service. In order to better grasp the preservationist approach, it seems necessary to take a closer look at the historical context. As the $19^{\text {th }}$ century drew to a close, a growing number of Americans came to an awareness of the fast pace of resource depletion in their country. Thus, members of the urban and educated middle class began to flock into green suburbs as early as in the late $19^{\text {th }}$ century (Schmitt 3). American historian Peter J. Schmitt has shown how nature captured the American imagination during the Progressive Era. This bears witness to the fact that many Americans experienced the side effects of material and industrial progress from which their country had benefited since the 1840s. In that respect the National Parks could give them a chance to take a break from industrial life and to reconnect with nature.

This led the preservationists to act in a somewhat ambiguous manner. Most of them endorsed the gospel of progress promoted by Theodore Roosevelt, and often took an active part in American expansion and the effort to take full control of the US territory. Simultaneously they bemoaned the harmful side effects of American progress. Their ambivalence about progress lies at the heart of the reformism of the Progressive Era. The members of the Sierra Club, most of them progressives, did not want the Parks to radically question the path of technologically-driven development that had been taken by their country. Instead, they regarded the Parks as a respite that would benefit the health of the nation and its inhabitants. Jacques Ellul's reflection on our difficulties in coping with the triumph of rationality sheds light on the function ascribed to the Parks by the preservationists: "[...] the most perfect machine remains purely rational [...] Man is not. In addition man is not rational in his feelings, opinions, behaviors but, what is more, he suffers in a purely and exclusively rational environment." $(1988,315-316)$ It was precisely because he was desperate to escape the domination of technology in all places that John Muir sought to promote the creation of protected areas beyond the reach of techno-industrial influence. 
37 Muir and his followers were aghast when they realized that the push for efficiency knew no bounds and went on unabated, giving short shrift to the fragile limitations imposed by the Park System. As steadfast proponents of the technological ethos, the conservationists took a stand against the inviolability of Parks. By contrast, the preservationists intended to prevent the Parks from being subjected to an enlightened brand of utilitarianism along the lines of the conservationist policies implemented in the National Forests. They would have preferred the Parks to remain untainted fragments of nature, valued for their beauty. Thanks to their consistent and one-sided approach, the conservationists did not find it very hard to counter the heterogeneous and sometimes contradictory arguments put forward by the preservationists who sounded out of step with the progressive emphasis on efficiency and practicality, as Kendrick A. Clements explains:

The opponents of the Hetch Hetchy project never really grasped the crucial function of the experts in the political process. Thus they misunderstood, or worse, ignored the experts' arguments; they made elementary technical blunders; they seldom sought competent technical advice; and they defended the wilderness with a romantic and aesthetic argument which made them vulnerable to charges of sentimentality and elitism. (Clements 1979, 299)

It is worth bearing in mind, for example, that the creation of Yellowstone National Park in 1872 had only been made possible by the recognition by elected officials that the areas concerned had been deemed unfit for commodity exploitation (Allin 28).

Such a rationale squares perfectly with the technological project which, according to Jacques Ellul, grants a secondary and minor role to aesthetics. In the framework of the technological society, aesthetics can never be expected to override the search for maximum efficiency. That is why opponents to the dam project were regularly dismissed as impractical sentimentalists, as exemplified in John Muir's portrayal in the San Francisco press (Righter 90). By contrast, Pinchot had always done his utmost to present scientific forestry as "unsentimental and probusiness" (Ficken 171). If it is commonly accepted that the areas designated as National Parks can only be regions with no commercial value-a shortcoming which tourism can remedy-the idea that Parks should remain inviolate becomes relative rather than absolute. In such circumstances, the integrity of the Parks can be put in the balance every time valuable resources are discovered in them. The inviolability of Parks, in other words, may only be a transitory phase.

\section{Conclusion}

The conservationist-preservationist dichotomy foreshadowed one of the major faultlines in contemporary US environmentalism. Although valuable in themselves and still tangible today, the preservationist achievements may always be put into question by the push for efficiency. In a society which aims to make the most of natural resources for the good of human communities, is it realistic to expect its members to abstain from exploiting resources which they are technologically capable of collecting and using? The quest launched by John Muir to preserve and expand the National Parks bears testimony to the limited prospects of preservationism in American life. To be sure, Muir did achieve remarkable success at times and his lasting popularity in contemporary environmental circles is well deserved. Yet, Muir, like his successors, 
also had to compromise on numerous occasions. Ironically enough, he never wavered in his support for automobile access to National Parks, thereby letting the machine in the garden. To him, easier access meant more tourists, which would then make it harder to dismantle the National Park System (Gunsky 202). What he did not anticipate was that this idea was to be so successful that a few decades after his death, the massive presence of motorized tourists would become a threat to the health of ecosystems in the parks. Americans were, as the saying goes, loving the Parks to death. Such a development shows how vulnerable any preservationist effort is bound to be.

Allin, Craig W. The Politics of Wilderness Preservation. 1982. Fairbanks: The University of Alaska Press, 2008.

Balogh, Brian. "Scientific History and the Roots of the Modern American State: Gifford Pinchot's Path to Progressive Reform." Environmental History 7:2 (2002): 198-225.

Chambers II, John W. The Tyranny of Change: America in the Progressive Era, 1890-1920. 1992. New Brunswick: Rutgers University Press, 2001.

Clements, Kendrick A. "Politics and the Park: San Francisco's Fight for Hetch Hetchy, 1908-1913." Pacific Historical Review 48:2 (1979): 185-215.

---. "Engineers and Conservationists in the Progressive Era." California History 58:4 (1979/1980): 282-303.

Cohen, Michael P. The Pathless Way: John Muir and American Wilderness. 1984. Madison: The University of Wisconsin Press, 1986.

Ellul, Jacques. La Technique ou l'enjeu du siècle. Paris: Librairie Armand Colin, 1954. ---. Le Bluff technologique. 1988. Paris: Hachette Littératures, 2004.

---. Ellul par lui-même: entretiens avec William H. Vanderburg. 1981. Paris: La Table Ronde, 2008.

Farquar, Francis P. History of the Sierra Nevada. 1965. Berkeley: University of California Press, 1972.

Ficken, Robert E. "Gifford Pinchot Men: Pacific Northwest Lumbermen and the Conservation Movement." Western Historical Quarterly 13:2 (1982): 165-178.

Frome, Michael. Battle for the Wilderness. 1974. Salt Lake City: The University of Utah Press, 1997.

Gunsky, Frederick R. South of Yosemite: Selected Writings of John Muir. 1968. Berkeley: Wilderness Press, 1988.

Gutfreund, Owen D. Twentieth-Century Sprawl: Highways and the Reshaping of the American Landscape. New York: Oxford University Press, 2004.

Hays, Samuel P. Conservation and the Gospel of Efficiency: The Progressive Conservation Movement, 1890-1920. 1959. Pittsburgh: The University of Pittsburgh Press, 1999.

Jones Holway R. John Muir and the Sierra Club: The Battle for Yosemite. San Francisco: Sierra Club, 1965.

Kolakowski, Leszek. La Philosophie positiviste. C. Brendel trans. 1966. Paris: Denoël, 1976. Louter, David. "Glaciers and Gasoline: The Making of a Windshield Wilderness 1900-1905." In Seeing and Being Seen: Tourism in the American West. Ed. David M. Wrobel et al. Lawrence: University Press of Kansas, 2001. 248-270.

Meyer, John M. "Gifford Pinchot, John Muir, and the Boundaries of Politics in American Thought." Polity 30:2 (1997): 267-284.

Miller, Char. "The Greening of Gifford Pinchot." Environmental History Review 16:3 (1992): 1-20.

---. Gifford Pinchot and the Making of Modern Environmentalism. Washington DC: Island

Press, 2001. 
---. "With Friends Like These: John Muir, Gifford Pinchot, and the Drama of Environmental Politics." In John Muir: Family, Friends, and Adventures. Ed. Sally M. Miller et al. Albuquerque: University of New Mexico Press, 2005. 121-146.

Muir, John. Our National Parks. 1902. San Francisco: Sierra Club Books, 1991.

---. A Thousand-Mile Walk to the Gulf of Mexico. 1916. Boston: Mariner Books, 1998.

Nash, Roderick F. Wilderness and the American Mind. 1967. New Haven: Yale University

Press, 2001.

Picon, Antoine. Les Saint-simoniens: raison, imaginaire et utopie. Paris: Belin, 2002.

Pinchot, Gifford. Breaking New Ground. 1947. Washington DC: Island Press, 1987.

Righter, Robert W. The Battle over Hetch Hetchy: America's Most Controversial Dam and the Birth of Modern Environmentalism. New York: Oxford University Press, 2005.

Runte, Alfred. National Parks: The American Experience. 1979. Lincoln, University of Nebraska Press, 1987.

Saint-Simon, Claude Henri de. "Du système industriel." 1821. In La Pensée politique de Saint-Simon. Textes. Ed. Ghita Ionescu. Paris: Aubier Montaigne, 1979. 164-193.

Schmitt, Peter J. Back to Nature: The Arcadian Myth in Urban America. 1969. Baltimore: The Johns Hopkins University Press, 1990.

Sellars, Richard W. Preserving Nature in the National Parks: A History. New Haven: Yale University Press, 1997.

Smith, Michael B. "The Value of a Tree: Public Debates of John Muir and Gifford Pinchot." The Historian 60:4 (1998): 557-578.

Steen, Harold K. The United States Forest Service: A History. 1976. Seattle: University of Washington Press, 2004.

Thoreau, Henry D. Walden and Resistance to Civil Government. 1854. Ed. William Rossi. New York: W.W. Norton \& Company, 1992.

Turner, Tom. David Brower: The Making of the Environmental Movement. Oakland:

University of California Press, 2015.

\section{NOTES}

1. The national forests were known as forest reserves until 1907 when they took their current name.

2. The "spoils system" was a patronage system through which an elected official appointed his political supporters to administrative positions regardless of their being competent. The spoils system came in for much criticism in the late $19^{\text {th }}$ century and during the Progressive Era. 


\section{ABSTRACTS}

This article tries to shed light on the ideology of early $20^{\text {th }}$-century utilitarian conservationists in the United States. It focuses on Gifford Pinchot, who was the first chief of the US Forest Service. After a comparison between Saint-Simonianism and utilitarian conservation, the article looks at Pinchot's approach to the National Parks, by drawing on Jacques Ellul's reflections on the ideological underpinnings of the technological society. The article ends with a discussion of the impact of Pinchot's approach to conservation on the chances of success of his preservationist adversaries during the Hetch Hetchy controversy in the early $20^{\text {th }}$ century. It suggests that the preservationist case, predicated on spiritual and aesthetic concerns, was doomed to be dismissed as impractical and sentimental in an era when the search for efficiency defined the public policy agenda to a considerable degree.

Cet article vise à éclairer l'idéologie des conservationnistes utilitaires américains du début du $20^{\mathrm{ème}}$ siècle. Il se concentre sur la personne de Gifford Pinchot, qui fut le premier directeur du Forest Service. Après une comparaison entre la pensée saint-simonienne et le conservationnisme utilitaire, l'article étudie, en utilisant les réflexions que Jacques Ellul a menées sur le système technicien, la manière dont Pinchot a abordé l'idée de parc national. L'article se conclut par une analyse de l'impact que la démarche de Pinchot a eu sur les chances de succès de ses adversaires préservationnistes lors de la controverse de Hetch Hetchy au début du $20{ }^{\mathrm{ème}}$ siècle. À une époque où la recherche de l'efficacité informait pour une large part les politiques publiques, l'argumentaire préservationniste, fondé sur des préoccupations esthétiques et spirituelles, était voué à être condamné pour son manque d'esprit pratique et son sentimentalisme.

\section{INDEX}

Mots-clés: conservation, environnementalisme, ère progressiste, foresterie, forêts nationales, parcs nationaux, préservationnisme, saint-simonisme, système technicien

Keywords: conservation, environmentalism, forestry, National Forests, National Parks, preservationism, Progressive Era, Saint-Simonianism, technological society

\section{AUTHORS}

\section{JEAN-DANIEL COLLOMB}

Maître de conférences

Université Jean Moulin, Lyon 3

jean-daniel.collomb@univ-lyon3.fr 